\title{
EL Salvador: Ex Post Evaluation of Exceptional Access Under the 2009 Stand-By Arrangement
}

This Ex Post Evaluation of Exceptional Access Under the 2009 Stand-By Arrangement with El Salvador was prepared by a staff team of the International Monetary Fund as background documentation for the periodic consultation with the member country. It is based on the information available at the time it was completed on August 30, 2010. The views expressed in this document are those of the staff team and do not necessarily reflect the views of the government of El Salvador or the Executive Board of the IMF.

The policy of publication of staff reports and other documents by the IMF allows for the deletion of market-sensitive information.

\footnotetext{
Copies of this report are available to the public from International Monetary Fund • Publication Services 700 19th Street, N.W. • Washington, D.C. 20431 Telephone: (202) 6237430 • Telefax: (202) 6237201

E-mail: publications@imf.org • Internet: http://www.imf.org
}

\section{International Monetary Fund Washington, D.C.}




\title{
INTERNATIONAL MONETARY FUND
}

\section{EL SALVADOR}

\section{Ex Post Evaluation of Exceptional Access under the 2009 Stand-By Arrangement}

\author{
Prepared by a Staff Team from the Strategy, Policy, and Review \\ and Western Hemisphere Departments ${ }^{1}$ \\ Authorized by the Western Hemisphere \\ and Strategy, Policy, and Review Departments
}

August 30, 2010

Contents Page

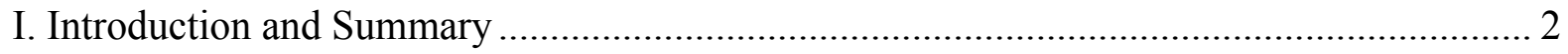

II. Why did El Salvador Request Fund Assistance? ..................................................... 4

III. Was Program-design Appropriate? ............................................................................. 5

IV. Did the Program Achieve its Objectives?.............................................................. 9

A. Comparative Macroeconomic Developments ....................................................... 11

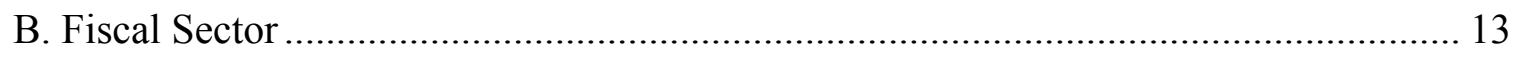

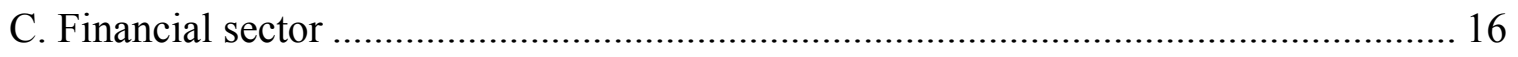

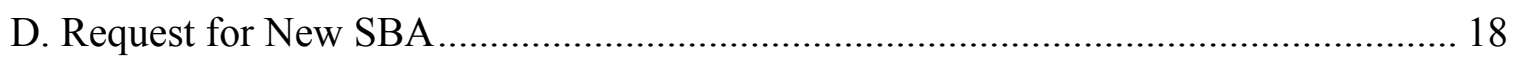

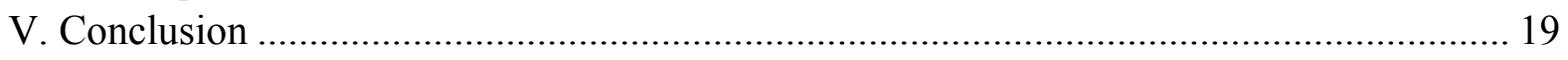

Tables

1. El Salvador: Quantitative Performance Measures for 2009 ......................................... 10

2. El Salvador: Structural Measures for 2009 ................................................................. 11

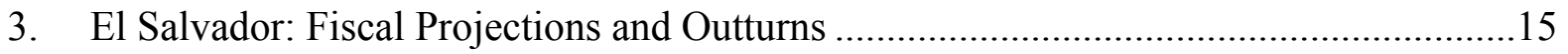

4. El Salvador: Financial System Projections and Outturns ....................................... 17

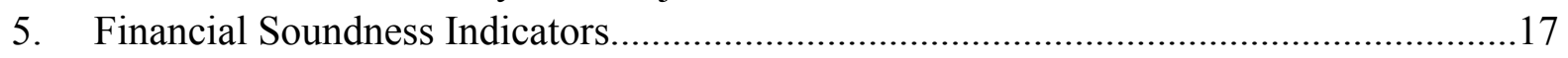

Figures

1. Macroeconomic Fundamentals on the Eve of the Crisis ............................................20

2. Relative Macroeconomic Performance..................................................................21

\section{Annexes}

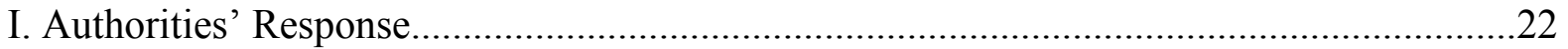

II. Public Statements by Presidential Candidates ..........................................................23

\footnotetext{
${ }^{1}$ The team comprised Reza Baqir (head, SPR), Sergi Lanau (SPR), and Andrew Swiston (WHD).
} 


\section{INTRODUCTION AND SUMMARY}

1. El Salvador requested a 15-month high-access precautionary Stand-By Arrangement (SDR 513.9 million, 300 percent of quota) in January 2009. The 2008 Article IV consultation noted El Salvador's strong macroeconomic fundamentals. Nevertheless, it faced two key uncertainties in late 2008: an unprecedented global financial crisis that was just beginning to reveal its scope and national elections in early 2009 with a possible change in government. Against these uncertainties, the authorities' key concern was that sudden deposit outflows around the elections could take a heavy toll on the open and formally dollarized economy. The primary objective of the program was to prevent a crisis of confidence by signaling policy continuity and providing a liquidity buffer in case such shocks materialized. In addition, the program sought to preserve macroeconomic stability by focusing on sustaining fiscal prudence and financial sector reforms.

\section{This ex-post evaluation of the 2009 Stand-By Arrangement assesses the} program's design and performance. Fund policy requires an ex post evaluation (EPE) of GRA-supported programs with exceptional access within a year after the end of the arrangement. ${ }^{2}$ This EPE focuses on the following questions: why did El Salvador request Fund assistance? (Section II); was program design appropriate? (Section III); did the program achieve its objectives? (Section IV); and what are the key lessons from the experience $($ Section $\mathrm{V}) ?^{3}$

\section{The program contributed to the achievement of its primary objective of} preventing a capital account crisis during the political transition. Evaluating the impact of a program is inherently complicated as the counterfactual-El Salvador's experience in the absence of a Fund-supported program - cannot be observed. Nevertheless, despite a heavy toll from the global crisis on the local economy and a change in government to the former opposition, El Salvador did not experience a crisis and preserved financial stability through the political transition. The program contributed to maintaining financial stability through its initial announcement effect, by providing a commitment device for the political parties ahead of the elections, and by facilitating dialogue during the political transition. A crisis would have been a sign of failure.

\footnotetext{
${ }^{2}$ See IMF Public Information Notice (PIN) No. 03/37 (03/21/03) and Ex Post Evaluations of Exceptional Access Arrangements Revised Guidance Note $(02 / 25 / 10)$. The arrangement was considered high access under the access limits prevailing in December 2008. Under the new access limits (GRA Lending Toolkit and Conditionality-Reform Proposals, 3/19/09) it would not have been considered high access.

${ }^{3}$ In accordance with procedures, this report was prepared at headquarters by an interdepartmental staff team, primarily on the basis of available documents and data. The team is grateful for conversations with present and former officials in El Salvador who were involved in the 2009 SBA, staff from the Inter-American Development Bank and the World Bank, and with former Fund mission chiefs and other Fund staff who were involved in the SBA. The key findings from the EPE were discussed with the authorities during a staff visit on August 17, 2010 and their general reactions are presented in Annex I.
} 
4. Nevertheless, the program had its share of challenges. The global crisis turned out to be much worse than expected in late 2008 and took a heavy toll on the Salvadoran economy. The program expected the economy to grow $2 \frac{1}{2}$ percent in 2009 ; in the event it contracted $3 \frac{1}{2}$ percent. As a result, the fiscal deficit for 2009 turned out $2 \frac{3}{4}$ percent of GDP higher than the program target, primarily due to cyclical factors. In addition, a key financial sector bill, programmed for passage in May 2009, was not passed. Instead of working toward completing the first review, the new administration — formerly the opposition — was keen to negotiate a new program for ownership reasons. In the event, the Stand-By Arrangement (SBA) was cancelled and a new and longer three-year SBA was approved in March 2010. Given the circumstances, it was appropriate to work towards a new SBA that had the ownership of the new authorities and placed a greater emphasis on addressing long-term fiscal challenges that emerged from the experience with the crisis.

\section{There are important lessons from the experience with the 2009 SBA.}

- $\quad$ Overall, El Salvador's experience shows that a quick and flexible response from the international community with a large financing package can help to prevent crises. The program was ahead of its time in effectively using High Access Precautionary Arrangements (HAPAs) for crisis prevention: subsequent reforms to the Fund's lending toolkit in March 2009 made HAPAs a more regular lending instrument (GRA Lending Toolkit and Conditionality_-Reform Proposals, 3/19/09).

- $\quad$ The program's approach of engaging both leading presidential candidates and the candidates' public endorsement of the program's main objectives were key ingredients to maintaining depositor confidence around the time of elections. Even though the program soon went off track, this investment in the relationship with the incoming authorities provided a useful framework for continued discussions on macroeconomic policies around the time of significant domestic and external uncertainties. Indeed, that the new administration wanted a new arrangement is a sign of the benefits of this engagement.

- $\quad$ At the same time, growth projections for El Salvador could have been marked down at the time of the SBA request in January 2009 given the deterioration in the external environment in fall 2008. A more conservative initial macroeconomic framework would have allowed for a smaller deviation between the program target for the fiscal balance and the outturn. Nevertheless, the initial macroeconomic framework should be seen in the context of extreme uncertainty in the global outlook in the aftermath of the collapse of Lehman Brothers; initial growth projections turned out to be optimistic for most Fund programs initiated during the early stages of the crisis.

- $\quad$ The delay in passage of the financial supervision reform bill limited progress in strengthening the financial sector's ability to withstand shocks, which was an important objective of the program. Nevertheless, the delay in passage should be seen 
in the context of other pressing priorities in 2009 as the real effects of the global crisis intensified, and this measure constitutes an important structural benchmark in the current SBA.

\section{Why did El SAlvador ReQUest Fund Assistance?}

6. El Salvador enjoyed strong macroeconomic fundamentals on the eve of the crisis. During the Board discussion of El Salvador's 2008 Article IV consultation on November 12, 2008, Executive Directors “welcomed the strength of El Salvador's macroeconomic fundamentals" which they noted was "the result of several years of sound policies, well-oriented structural reforms, and a favorable external environment." ${ }^{\text {Data }}$ from before the crisis show that El Salvador was close to the average emerging market (EM) on several vulnerability indicators (Figure 1$).{ }^{5}$

7. Nevertheless, the global crisis and the U.S. recession posed external challenges to EI Salvador. Being a small, open, and officially dollarized economy with tight links to the U.S. economy, El Salvador was exposed to a slowdown in trade and remittances and volatility in capital flows. These risks were also duly noted in the 2008 Article IV consultation where the Board's assessment noted that the policy priorities were "to improve crisis preparedness in the financial sector, maintain fiscal restraint, and secure government financing in the coming year."

\section{In addition, electoral uncertainties had the potential to amplify the external} shock and cause deposit flight. Congressional and presidential elections were slated for January and March 2009, respectively, and political uncertainty had intensified in the run-up to the elections. Historically, Salvadoran politics had remained polarized between the two main parties: Alianza Republicana Nacionalista (ARENA) and Frente Farabundo Martí para la Revolución Nacional (FMLN). The possibility of a strong showing by the left-leaning FMLN raised concerns about policy continuity and heightened the risk of capital and deposit outflows. ${ }^{6}$ During the previous presidential elections in 2004, deposits had proven to be volatile: several banks lost more than 5 percent of deposits in a period of three weeks amidst widespread transfers of residents' deposits from local to foreign affiliates of international financial conglomerates, with one small bank losing nearly 30 percent of deposits. Given the 2004 experience, heightened political uncertainty, and a much weaker external environment, the authorities were concerned in late 2008 about the potential for deposit outflows.

\footnotetext{
${ }^{4}$ IMF Public Information Notice No. 08/151.

${ }^{5}$ The NPL ratio has to be interpreted with caution in cross-country comparisons as definitions of what constitutes an NPL vary across countries.

${ }^{6}$ In the event, the FMLN's victory marked the first leftist government since the end of the civil war in 1992.
} 
9. The combination of external and domestic uncertainties in the context of a dollarized economy motivated the request for external assistance. As an officially dollarized economy, El Salvador entered the crisis with a limited ability to cope with potentially large banking shocks. Commercial banks maintained reasonably high liquid asset ratios at end-2008 of around 25 percent of private sector deposits but these could not be pooled to assist an individual bank whose liquidity needs may exceed its liquid assets. The central bank was constrained by its low level of free reserves - mostly government deposits at the central bank - in undertaking lender-of-last-resort operations. Thus the authorities saw value in a Fund arrangement to serve as a signal of macroeconomic policy continuity and buffer against potential liquidity stress in banks.

\section{Was Program Design ApPropriate?}

10. The program's main objectives were to prevent deposit flight, preserve macroeconomic stability, and boost the economy's resilience to shocks. ${ }^{7}$ The program focused on three key areas:

- $\quad$ signal overall policy continuity in the face of electoral uncertainty and support depositor confidence by strengthening liquidity buffers of the banking system to cope with possible sudden deposit outflows during the election period;

- $\quad$ support continued fiscal prudence; and

- $\quad$ strengthen financial regulation and supervision to improve the banking system's capacity to withstand shocks.

\section{Overall policy continuity was signaled through public pronouncements} supportive of the program by both leading presidential candidates. Securing broad support for the Fund-supported program from the two main presidential candidates was a key accomplishment of the program. Specific actions helped secure this goal. The opposition presidential candidate visited the IMF in late 2008 with his economic team and discussed with Fund staff his vision for economic policies for El Salvador. The December 2008 mission also met with the opposition to have an exchange on appropriate economic policies for El Salvador. Perhaps most significantly, both presidential candidates posted statements broadly supportive of the Fund-supported program on their campaign web sites (Annex II). They also expressed their support for the dollarization regime. In this respect, the program was similar to Brazil's 2002 SBA that also sought engagement with the opposition parties to support investor confidence during elections.

${ }^{7}$ IMF Country Report No. 09/71 (01/09/2009). 


\section{The Fund supported depositor confidence by committing adequate resources} under the precautionary arrangement. For the program's credibility it was important that it be perceived as having adequate resources should a need arise. The key challenge was to have enough liquidity buffers in case banks experienced deposit outflows. Banks' most liquid assets comprised 25 percent of banking system deposits as of November 2008 (text table). The experience of other countries suggested that in extreme cases, system-wide deposit outflows could reach 25 percent (e.g., Uruguay 2001/02). Access under the SBA of 300 percent of quota was calculated to yield liquid asset coverage of bank deposits to around 35 percent (including banks' own most liquid assets) to provide an extra buffer compared to other experiences. The speed with which deposit outflows could occur justified the need for significant frontloading of access, with 200 percent of quota (SDR 342.6 million) made available at program approval. Access was high in terms of annual limits prevailing at the time but not high in terms of cumulative limits.

Banking System Liquidity (liquid asset holdings; in percent of private sector deposits)

\begin{tabular}{lrrr}
\hline & Dec-07 & Jun-08 & Nov-08 \\
\hline Most liquid & $\mathbf{2 1 . 1}$ & $\mathbf{2 2 . 0}$ & $\mathbf{2 4 . 7}$ \\
Deposits at BCR & 15.1 & 13.8 & 15.7 \\
Deposits abroad & 2.8 & 4.3 & 2.8 \\
Securities abroad & 3.3 & 4.0 & 6.2 \\
Subject to funding constraints & $\mathbf{1 6 . 1}$ & $\mathbf{1 6 . 1}$ & $\mathbf{1 5 . 3}$ \\
$\quad$ Central government securities & 4.3 & 4.5 & 3.8 \\
$\quad$ Central Bank securities & 11.8 & 11.6 & 11.5 \\
Operational liquidity (cash) & $\mathbf{2 . 8}$ & $\mathbf{2 . 0}$ & $\mathbf{2 . 3}$ \\
Total & $\mathbf{3 9 . 9}$ & $\mathbf{4 0 . 1}$ & $\mathbf{4 2 . 3}$ \\
Potential Fund support (300\% of quota) & & & 9.3 \\
Most liquid plus Fund support & & & 34.0 \\
& & & \\
Memo items (million U.S. dollars) & & & \\
Total private sector deposits & 8,641 & 8,527 & 8,536 \\
Total liquidity & 3,450 & 3,421 & 3,608 \\
$\quad$ Most liquid & 1,825 & 1,879 & 2,110 \\
Potential Fund support (300\% of quota) & & & 795 \\
\hline Sorce IMF County Repot & & &
\end{tabular}

Source: IMF Country Report No. 09/71.

\section{In line with the exceptional access procedures at the time, the SBA request was} assessed in light of the exceptional access criteria. Since El Salvador's program was approved before the Board decisions that modified exceptional access criteria (GRA Lending Toolkit and Conditionality_-Reform Proposals, 3/19/09) its request for exceptional access is assessed under the old criteria for exceptional access (PIN 03/37, 3/21/03):

- $\quad$ First criterion: "the member is experiencing exceptional balance of payments pressures on the capital account resulting in a need for Fund financing that cannot be met within the normal limits." The paper recognized that exceptional balance of payments pressures on the capital account had not yet materialized but also argued that there was a significant risk that such pressures could arise. Therefore, the criterion was not met. But in the context of the 2004 review of exceptional access policy, it was acknowledged that "in rare circumstances a need for exceptional access could arise in situations other than a capital account crisis, and that in those cases a member could not be expected to meet all four criteria" (PIN 04/54, 05/13/04). ${ }^{8}$ For

\footnotetext{
${ }^{8}$ In March 2009 the first criterion for exceptional access was broadened to include cases where the member "has the potential to experience exceptional balance of payment pressures."
} 
instance, the 2005 SBA for Uruguay is another rare case where exceptional access was approved despite the absence of capital account pressures. Given the adverse external environment and political uncertainty, the assessment in the program was appropriate.

- Second criterion: "a rigorous and systematic analysis indicates that there is a high probability that debt will remain sustainable." This criterion was satisfactorily assessed to have been met in the SBA request. The debt sustainability analysis showed that, under a variety of plausible shocks, the debt stock would remain at manageable levels. The moderate initial debt level and the sound track record of fiscal policy implementation also gave confidence that there was a high probability that debt would remain sustainable.

- Third criterion: "the member has good prospects of regaining market access within the time that Fund resources would be outstanding, so that the Fund's financing would provide a bridge." The 2009 SBA request staff report acknowledged that access to capital markets at the time was limited but also pointed out that El Salvador's rating was either investment grade (Moody's) or just one notch below investment grade (S\&P and Fitch). During 2009, El Salvador was downgraded one notch by the agencies but also placed an $\$ 800$ million Eurobond successfully.

- $\quad$ Fourth criterion: "the policy program of the member provides a reasonably strong prospect of success, including not only the member's adjustment plan but also its institutional and political capacity to deliver that adjustment." This criterion was assessed candidly. El Salvador's adherence to dollarization since 2001 has required a good track record of sound policies and structural reforms. It entered the crisis with moderate debt levels and its banking system was well-capitalized and liquid. This provided confidence in the authorities' ability to implement the program. As argued below, the failure to complete the first review of the SBA can be traced back to the global environment rather than a lack of commitment on the part of the authorities.

14. There was an appropriate level of early Board involvement in the period leading to the SBA request. A Board meeting was held on December 19, 2008 to discuss the need for an SBA involving exceptional access. A report assessing the risks to the Fund and the Fund's liquidity position was provided to the Board, consistent with exceptional access procedures. ${ }^{9}$

\footnotetext{
${ }^{9}$ GRA Lending Toolkit and Conditionality-Reform Proposals - Revised Proposed Decisions, Supplement 1 (03/19/09).
} 
15. Program conditionality appropriately focused on crisis prevention measures, maintaining fiscal prudence, and strengthening the financial sector. In addition to measures aimed at bolstering the liquidity of the banking system, program conditionality focused on issues that had been identified in the 2008 Article IV consultation.

- Crisis prevention and boosting bank liquidity. As a prior action for the program, the authorities implemented a regulation to make the central bank a clearing house for interbank transactions. This enhanced the functioning of the interbank market, facilitated the allocation of liquidity among banks, and improved the effectiveness of central bank intervention. This measure came on the back of other actions in the second half of 2008 to ensure bank soundness.

- Maintaining fiscal prudence. Given El Salvador's strong fundamentals and the precautionary nature of the SBA, the fiscal program did not envisage a large amount of adjustment. The estimated non-financial public sector deficit for 2008 at the time of the SBA negotiation was 2.9 percent of GDP, and public sector debt was estimated at 40 percent of GDP. The primary balance target was set near the debt-stabilizing level and unchanged from the expected 2008 outturn (text table). Given the moderate deceleration in the growth forecast, the fiscal impulse - measured as the change in the cyclically-adjusted fiscal balance-was expected to be minus 0.2 percent of GDP, based on some tax administration measures, while planned savings from an elimination of the nonresidential electricity subsidy were to be diverted to cash transfer programs for low-income households.

Primary Balance: Program and Sensitivity

\begin{tabular}{lc}
\hline & $\begin{array}{c}\text { Primary balance } \\
\text { for } 2009 \\
\text { (percent of GDP) }\end{array}$ \\
\hline Program & -0.5 \\
Debt stabilizing primary surplus under: & \\
Program macro assumptions & 0.0 \\
Historical performance & -0.8 \\
Interest rate shock & 0.3 \\
Growth shock & 0.5 \\
Combined shock & 0.4 \\
\hline
\end{tabular}

Sources: IMF Country Report No. 09/71; and Fund staff calculations.

- $\quad$ Strengthening financial regulation and supervision. The conditionality to strengthen the financial system was in line with the issues identified in the 2008 Article IV consultation. The main structural benchmark in the program sought passage of a bill that would (i) merge the supervisory entities for banks, pension funds, and securities markets; (ii) enhance the autonomy of the merged supervisory institution; (iii) strengthen legal protection for supervisors; and (iv) strengthen cross-border consolidated supervision.

16. The program also included two consultation clauses as key safeguard measures. Since El Salvador is a dollarized economy, the standard floor on NIR was not considered appropriate, as it could have undermined the program's confidence-enhancing effects by constraining the central bank's ability to provide liquidity to banks experiencing deposit outflows. Instead the program contained two consultation clauses to ensure that the 
authorities and Fund staff would reach understandings on corrective measures in the event of liquidity strains. The first would be triggered if the sum of total deposits in commercial banks, plus external short-term bank liabilities of commercial banks with an original maturity of up to one year, fell by 10 percent with respect to its end-November 2008 level. This was considered to be a better trigger than one on NIR since the key objective was to catch the first signs of capital flight and NIR could fluctuate due to changes in public sector deposits and shifts in the maturity structure of private sector deposits. The second consultation clause would be triggered if the authorities decided to lower system-wide commercial bank reserve or liquid asset requirements. For monitoring purposes, the authorities provided, on a daily basis, bank-level data on total deposits and liquidity positions, and, on a weekly basis, banklevel data on outstanding short-term external liabilities.

17. Overall, conditionality was kept streamlined. This was appropriate considering the key objective of the program was to signal policy continuity and in light of El Salvador's strong fundamentals noted in the 2008 Article IV consultation. There were also concerns that a program with onerous conditions may be perceived as a signal of weaknesses in the Salvadoran economy.

\section{Did the Program Achieve its OBJectives?}

\section{The program contributed to its} primary objective of bolstering confidence and preventing banking and capital account crises and the authorities did not need to make the first purchase. Bank deposits proved to be stable during the period, a marked departure from the previous elections in 2004 (text figure) and a key objective of the program. El Salvador's sovereign spreads generally co-move with the regional average but began to separate from it in late 2008 signaling rising investor uncertainty in the runup to elections. However, the gap closed after the announcement of the staff-level agreement. Between end-2008 and the approval of the SBA, sovereign spreads declined by 100 basis points compared with 30 basis points for the regional composite. Also, importantly El Salvador's spreads did not rise around the two key election dates. Spreads remained in line with the regional composite even though the program went off-track (text figure).

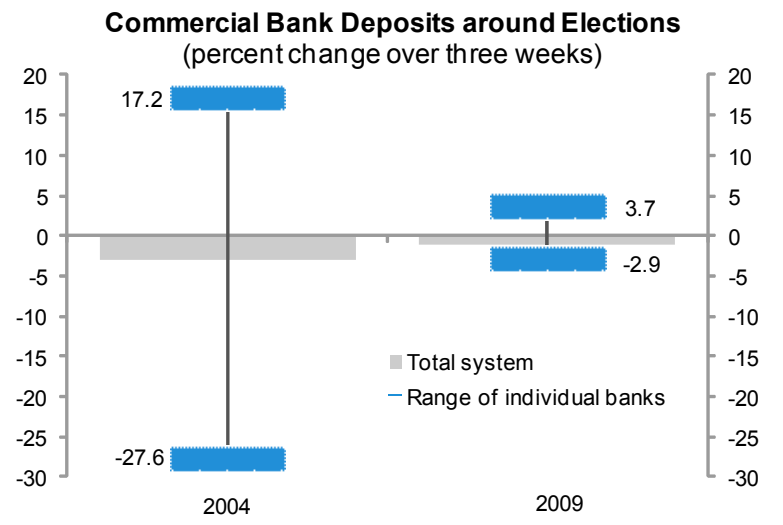

Source: Central Reserve Bank of El Salvador; and Fund staff

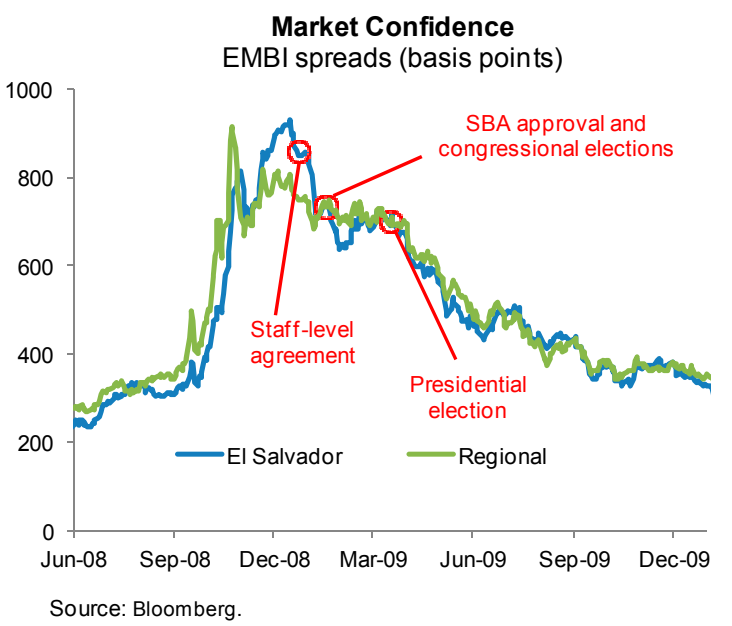


19. The Board and the general public were kept abreast of developments when the program went off track. A press statement was released on May 27, 2009 (IMF Press Release No. 09/188) welcoming the incoming authorities' commitment to maintaining macroeconomic stability and reiterating the IMF's disposition to maintain a close relationship with the new government. In mid-June, 2009 Fitch Ratings noted in a report that the "precautionary SBA with the IMF ... served well to support financial stability through external turbulence and the electoral cycle." 10 The Board was informed of recent developments through an informal country matters session in September 2009. Even though the program could have been amended to reflect the deteriorating external environment, staff and the authorities agreed that a new program would be a better option in the context of a political transition.

\section{This section reviews program performance compared to other countries and} program objectives. It first puts macroeconomic developments in El Salvador in a crosscountry perspective. Next, it describes the outturns in the fiscal and financial sectors compared to programmed objectives, focusing on outturns for 2009 which roughly coincides with the period until the arrangement was canceled. Finally, it provides background on the factors that led to the request for a new SBA. Tables 1 and 2 list the performance criteria (PCs) and structural benchmarks in the SBA.

Table 1. El Salvador: Quantitative Performance Measures for 2009 (In million U.S. dollars)

\begin{tabular}{|c|c|c|c|c|c|c|c|c|}
\hline & \multicolumn{2}{|c|}{ end-March } & \multicolumn{2}{|c|}{ end-June } & \multicolumn{2}{|c|}{ end-September } & \multicolumn{2}{|c|}{ end-December } \\
\hline & Program & Actual & Program & Actual & Program & Actual & Program & Actual \\
\hline \multicolumn{9}{|l|}{ Performance criterion } \\
\hline $\begin{array}{l}\text { Overall balance of the non-financial } \\
\text { public sector (cumulative floor) }\end{array}$ & -150 & -264 & -201 & -473 & -427 & -753 & -669 & $-1,171$ \\
\hline $\begin{array}{l}\text { Continuous performance criterion } \\
\text { Accumulation of new external arrears } \\
\text { of the NFPS (ceiling) }\end{array}$ & 0 & 0 & 0 & 0 & 0 & 0 & 0 & 0 \\
\hline \multicolumn{9}{|l|}{ Quantitative benchmark } \\
\hline $\begin{array}{l}\text { Total bank deposits plus external } \\
\text { short-term bank liabilities (floor) }\end{array}$ & 8,303 & 9,204 & 8,303 & 9,054 & 8,303 & 9,020 & 8,303 & 9,185 \\
\hline
\end{tabular}

Source: IMF Country Report No. 09/71; Central Reserve Bank of El Salvador; and Ministry of Finance.

\footnotetext{
${ }^{10}$ Fitch Ratings, El Salvador, June 24, 2009.
} 
Table 2. El Salvador: Structural Measures for 2009

\begin{tabular}{lr}
\hline & Status \\
\hline Prior action & \\
Implement regulation to increase effectiveness of central bank intervention in interbank & Completed \\
lending market. & \\
Structural benchmarks & Kept \\
Maintain prudential reserve requirements of banking system, currently at about 22 percent & \\
in effective terms (continuous). & Structural \\
May 15 & Benchmark \\
Pass financial supervision bill containing following elements: & for 2010 \\
i) Merge the supervisory entities for banks, pensions and the stock market & SBA \\
ii) Enhance the autonomy of the merged supervisory institution & \\
iii) Strengthen legal protection for supervisors & \\
iv) Strengthen cross-border consolidated supervision. & \\
\hline
\end{tabular}

Source: IMF Country Report No. 09/71.

\section{A. Comparative Macroeconomic Developments}

\section{Overall macroeconomic developments in EI Salvador were similar to a broad} sample of emerging markets (EMs). Growth in 2009 was similar to the average for all EMs with programs though inflation was considerably lower (Figure 2). The primary balance deteriorated by a similar amount as EMs with programs although less so than all EMs. That said, the rise in public debt was slightly more. Compared to other EMs, exports fell sharply in El Salvador.

\section{As in other countries, the global crisis had a larger-than-expected impact on El} Salvador. Compared to initial program projection of 21/2 percent, growth in 2009 turned out to be $-3 \frac{1}{2}$ percent, driven by a much larger-than-expected fall in consumption (text table). The fall in external demand, remittances, and confidence contributed to the growth slowdown. While considerable, the deviation of growth from initial projections was in line with other countries in the region and less than El Salvador: Contributions to 2009 Real GDP Growth (percent)

\begin{tabular}{lcc}
\hline & SBA projection & Actual outcome \\
\hline Real GDP growth & 2.5 & -3.5 \\
Contributions to growth: & & \\
Consumption & -1.6 & -9.8 \\
Investment & 0.3 & -3.1 \\
Net exports & 3.8 & 9.4 \\
\hline
\end{tabular}
in several EMs with programs (text figure). This was in part because WEO growth projections were in the process of being marked down. 


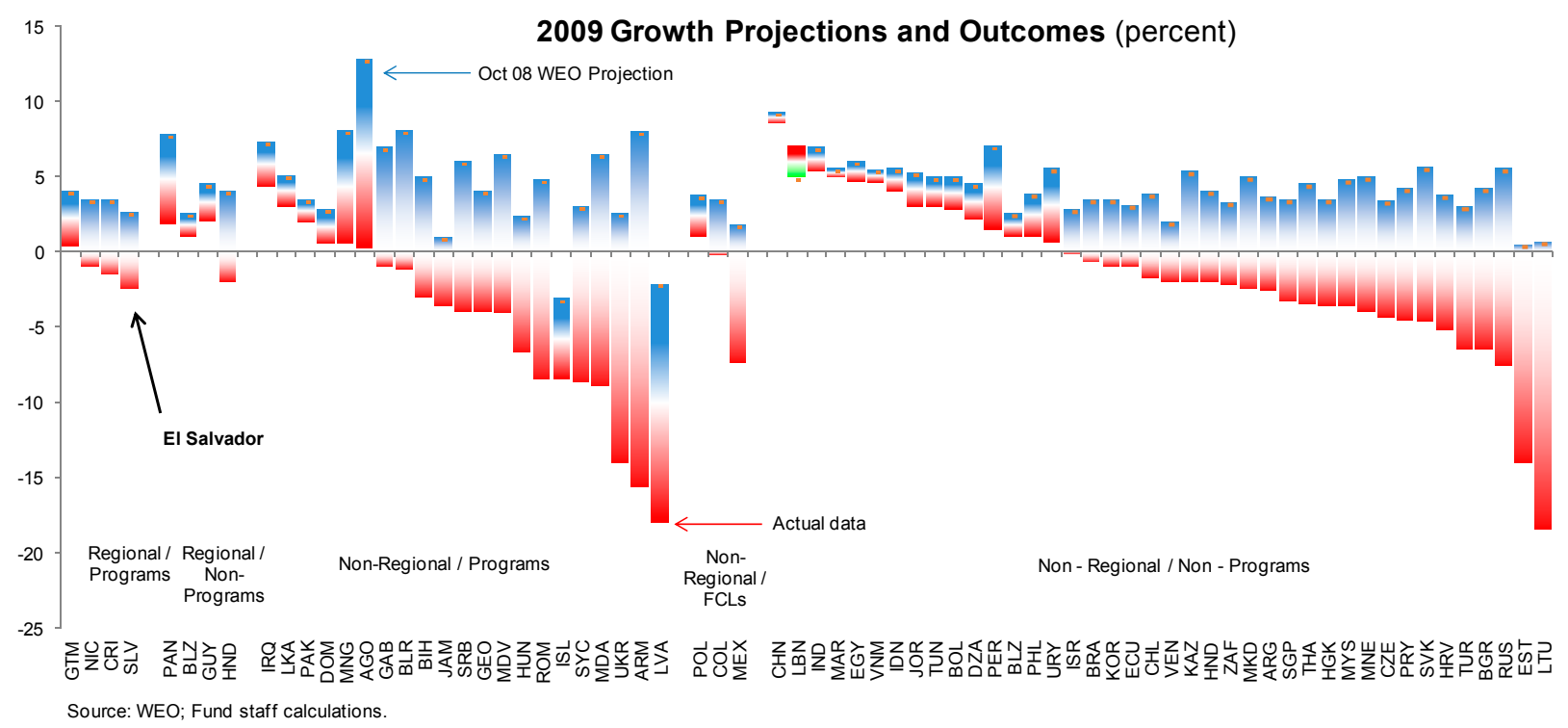

23. While growth markdowns were a general phenomenon, the initial macroeconomic framework could have been more conservative. Comparing the timing of growth markdowns, projected world and U.S. growth for 2009 was marked down by nearly one percentage point between the Fall 2008 WEO and the November 6, 2008 WEO update but left unchanged over roughly the same period for El Salvador (text table). The 2008 Article IV consultation staff report noted - in the context of discussing risks to the outlookthat the elasticity of El Salvador's economic cycle with respect to the U.S. cycle was close to one. This proved to be an under-estimate as growth in El Salvador

GDP Growth, 2009

(In percent)

\begin{tabular}{lrrr}
\hline & World & U.S. & 日 Salvador \\
\hline Projection as of: 1/ & & & \\
Oct. 2, 2008 & 3.0 & 0.1 & 2.0 \\
Nov. 6, 2008 & 2.2 & -0.7 & 2.5 \\
Actual outturn & -0.6 & -2.4 & -3.5 \\
Difference from Oct 2 projection: & & & \\
Nov. 6, 2008 & -0.8 & -0.8 & 0.5 \\
Actual outturn & -3.6 & -2.5 & -5.5 \\
2009 less 2008 grow th & -3.6 & -2.8 & -6.0 \\
\hline
\end{tabular}

Source: WEO; Fund staff calculations.

1/ For $\boxminus$ Salvador, dates correspond to grow th projections in the 2008 Article N consultation (Nov. 12, 2008) and the Request for Stand-By Arrangement (January 15, 2009, staff statement). fell much more than in the United States between 2009 and 2008; and the spillover from the U.S. economy was much larger than expected. However, this assessment has to be taken with the caveat that the last quarter of 2008 was a period of extreme uncertainty and rapid deterioration in the global outlook in the aftermath of the collapse of Lehman Brothers. 


\section{B. Fiscal Sector}

24. The sharper-than-expected growth slowdown led to a significant breach of the fiscal balance target. The end-March PC on the overall balance of the nonfinancial public sector was missed by US\$114 million

( $1 / 2$ percent of annual GDP). The May 2009 mission for the first review estimated that on unchanged policies the deficit for 2009 could reach 5.4 percent of GDP against the program target of 2.8 percent of GDP. In the event, the deficit for the year turned out to be 5.6 percent of GDP. El Salvador's experience was in line with many other EMs with programs where fiscal projections as of late 2008 proved to be optimistic (text figure).

The actual deficit for 2009 was also not out of line compared to other program countries.

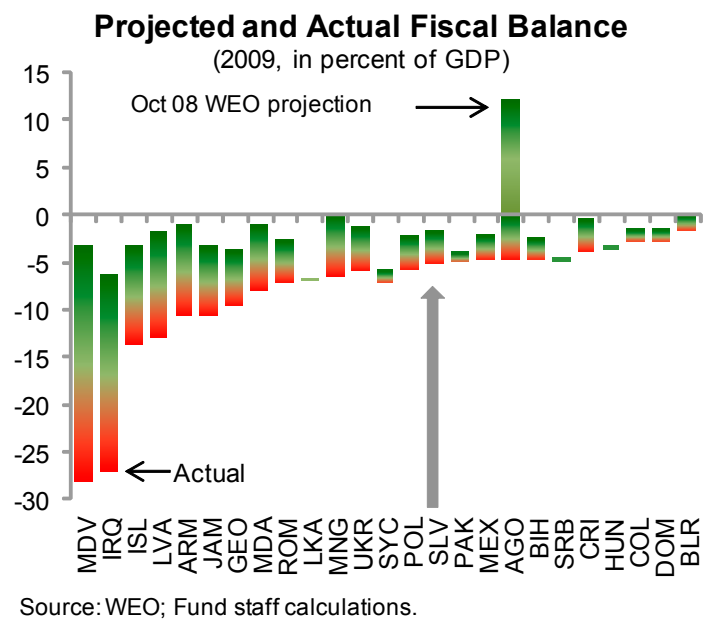

\section{The deviation of the fiscal deficit from the original program owed almost} entirely to the cyclical effects of the recession on tax revenue. Total revenue came in about US\$650 million (3.1 percent of GDP) below program projections, with most of the gap due to lower-than-programmed tax revenue (text figure and Table 3). Tax revenue growth remained strong at 9 percent in the year through October 2008, but began to fall in November, driven by a 7 percent decline in VAT revenue in the last two months of the year. Weakness intensified in early 2009, with tax revenue falling by 7 percent year-on-year in the first quarter. Of the $\$ 114$ million gap in the fiscal balance in 2009Q1, \$100 million was accounted for by a shortfall in revenues. The deterioration in revenue was primarily cyclical, as there were no tax cuts during 2009. The staff report for the 2009 SBA underestimated the recession's impact on the fiscal balance. It noted that "weaker than envisaged output growth would have a small effect on the fiscal balance" (IMF Country Report No. 09/71, 01/09/2009, ๆ11). The difference arose primarily due to a higher-than-expected elasticity of revenues with respect to GDP.

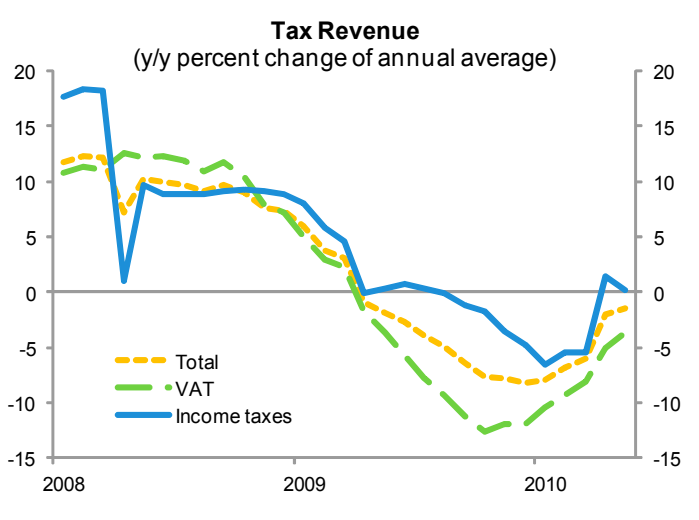

Source: Ministry of Finance; and Fund staff calculations

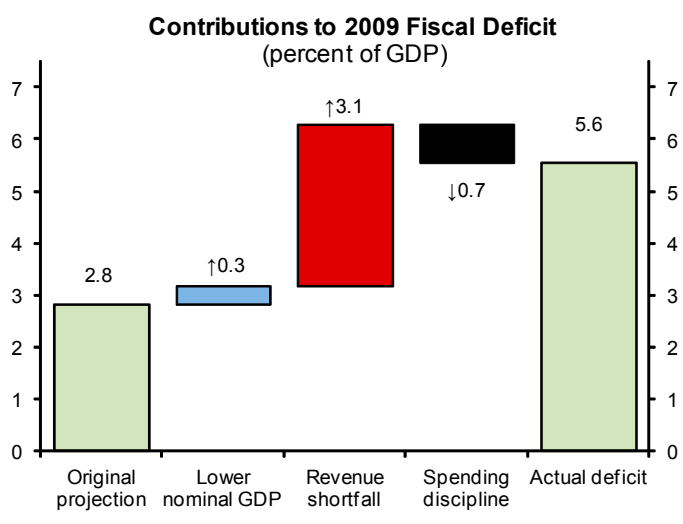

Source: Ministry of Finance; and Fund staff calculations. 


\section{Despite the political transition, the outgoing and incoming authorities} successfully maintained overall expenditure restraint. For the year as a whole, the revenue shortfall of more than $\$ 650$ million was partly offset by expenditure savings of over $\$ 150$ million.

- $\quad$ The outgoing authorities enacted some expenditure cuts despite the weak economy. In early 2009, expenditure was in line with targets, as energy subsidy outlays remained high and there was some execution of projects postponed from 2008. As revenue began to fall short of projections, the outgoing authorities reduced the electricity subsidy to residential customers and eliminated the subsidy to commercial customers ahead of schedule, generating annual savings of US\$75 million. An executive decree freezing most government hiring and ordering line ministries to apply austerity measures yielded a further US\$20 million in annual savings.

- The incoming authorities, upon assuming office in June 2009, shifted expenditures toward high-priority social needs in light of the economic downturn, financing this spending through cuts elsewhere to keep overall expenditure below the levels envisaged in the program. Their flagship anti-crisis plan envisaged increased social spending averaging 1 percent of GDP over 2009-11 to mitigate the effects of the crisis on the poor, through temporary work programs, the provision of free medicines to hospitals and uniforms for school children, and social investment projects. To finance these programs, the authorities cut the subsidy to transportation operators in half while maintaining the excise taxes earmarked for the subsidy. ${ }^{11}$ They also extended and deepened the austerity measures implemented by the previous administration, and reviewed the entire capital spending program to re-prioritize projects, which led to $\$ 150$ million less in public investment relative to program. Overall these measures allowed the authorities to reorient spending while exercising expenditure control.

\footnotetext{
${ }^{11}$ This brought outlays for the subsidy into line with receipts from the dedicated revenue sources.
} 
Table 3. El Salvador: Fiscal Projections and Outturns 1/

\begin{tabular}{|c|c|c|c|c|c|}
\hline & SBA 09 2/ & Actual & Deviation & SBA 09 2/ & Actual \\
\hline & \multicolumn{3}{|c|}{ (million U.S. dollars) } & \multicolumn{2}{|c|}{ (percent of GDP) } \\
\hline Revenue and grants & 4,059 & 3,400 & -659 & 17.2 & 16.1 \\
\hline Tax revenue & 3,216 & 2,609 & -606 & 13.6 & 12.4 \\
\hline Expenditure & 4,728 & 4,571 & -157 & 20.1 & 21.7 \\
\hline Current expenditure & 3,938 & 3,929 & -9 & 16.7 & 18.6 \\
\hline Wages and salaries & 1,705 & 1,659 & -45 & 7.2 & 7.9 \\
\hline Goods and services & 830 & 874 & 44 & 3.5 & 4.1 \\
\hline Interest & 541 & 531 & -10 & 2.3 & 2.5 \\
\hline Current transfers & 862 & 865 & 3 & 3.7 & 4.1 \\
\hline Nonpension payments & 505 & 519 & 14 & 2.1 & 2.5 \\
\hline Pension payments & 357 & 346 & -11 & 1.5 & 1.6 \\
\hline Capital expenditure & 790 & 642 & -148 & 3.4 & 3.0 \\
\hline Primary balance & -128 & -640 & -512 & -0.5 & -3.0 \\
\hline Overall balance & -669 & $-1,171$ & -502 & -2.8 & -5.6 \\
\hline
\end{tabular}

Sources: Central Reserve Bank of El Salvador; Ministry of Finance; and Fund staff estimates.

1/ Non-financial public sector.

2/ IMF Country Report No. 09/71.

\section{The experience with the large growth surprise raises the question whether} conditionality should have included a cyclically-adjusted measure. For example, a PC on the overall deficit and an expenditure ceiling could have strengthened the case for completing the first review. If one of the fiscal PCs had been met it might have bolstered the case that the cyclical deterioration could be accommodated. A more ambitious approach would have targeted a cyclically-adjusted fiscal balance with a floor on the overall fiscal balance. However, such a PC would be difficult to implement and communicate. Computation of cyclically-adjusted balances is a challenging task even in advanced economies where data quality is better. It is harder in emerging markets, especially in a small open economy like El Salvador subject to external shocks. Also, national accounts data typically are available after a longer lag than fiscal data making it practically difficult to use such a measure as PC.

\section{The higher deficit was financed through reorientation of MDB loans and}

Eurobond issuance. Congress had approved in late 2008 US\$950 million in budget support loans from the IDB and World Bank to be disbursed over 2009-11. ${ }^{12}$ The agreement earmarked US\$300 million for specific social investment projects and US\$650 million to amortize a Eurobond maturing in 2011. In May 2009, the outgoing and incoming

\footnotetext{
${ }^{12}$ Long-term financing requires a two-thirds majority in congress.
} 
administrations, as well as all congressional parties, reached agreement to allow these funds to finance the deficit. ${ }^{13}$ They also authorized the issuance of a Eurobond to amortize the 2011 bond, as well as additional Eurobond issuance of up to US\$800 million, which was placed in November. ${ }^{14}$ Given the availability of other sources of financing, including access to international capital markets, budgetary support through access to Fund financing was not considered necessary. Public sector debt rose from 41 percent to 50 percent of GDP, driven by the decline in nominal GDP, the higher deficit, and an accumulation of deposits from the Eurobond issuance that is being drawn down in 2010-11 (text table).

Decomposition of Debt Performance (In percent of GDP)

\begin{tabular}{lcc}
\hline & 2008 & 2009 \\
\hline Non-financial public sector debt, actual & 41.2 & 50.4 \\
SBA projection & 41.5 \\
Projection error & 8.9 \\
Higher fiscal deficit & 2.4 \\
Lower nominal GDP & 4.9 \\
Other, including higher deposit accumulation & 1.6 \\
\hline
\end{tabular}

Sources: IMF Country Report No. 09/71; and Fund staff calculations.

\section{Financial sector}

\section{The financial system withstood the global crisis and period of electoral}

uncertainty. A key objective of the program was to avoid deposit flight during the political transition. In contrast with the 2004 elections, no deposit flight from individual banks was experienced, despite deposits trending downward system-wide in early 2009. No bank encountered shortfalls in liquidity. Net international reserves remained stable, in line with deposits. While the counterfactual outcome cannot be observed, the lack of deposit flight amid a turbulent external environment

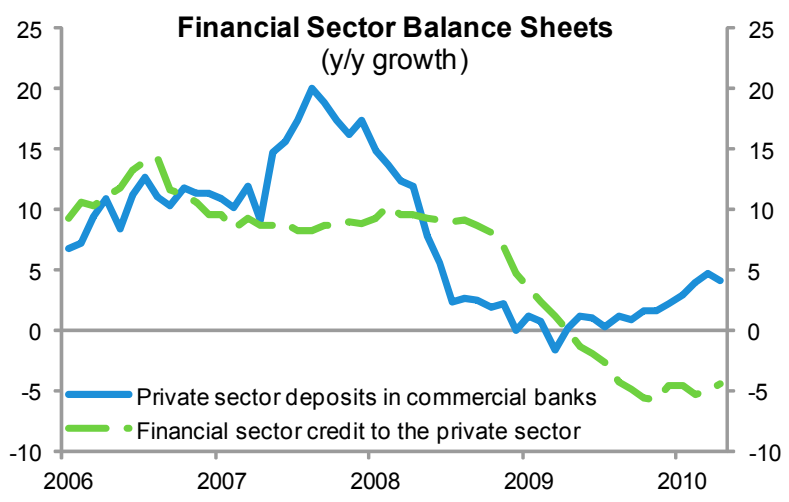
suggests that the statements issued by both Source: Central Reserve Bank of El Salvador; and Fund staff calculations. leading presidential candidates endorsing the SBA and in support of dollarization and macroeconomic stability contributed to confidence in the financial system.

\section{The global crisis and downturn in activity hit bank lending hard despite}

measures undertaken by the authorities. Credit to the private sector began to drop in late 2008 and fell by 4.6 percent in 2009, undershooting the SBA projection by over 10 percent (Table 4). Deposit growth hovered above zero for most of the first half of 2009 but

\footnotetext{
${ }^{13}$ Another component of the agreement was the placement of about US\$300 million in short-term debt with commercial banks for immediate financing needs, including to avoid incurring domestic arrears.

${ }^{14}$ The September 2009 staff-level agreement on a new three-year SBA was seen by investors as a positive signal on the authorities' plans for fiscal consolidation.
} 
eventually picked up and reached 2.3 percent for the year as a whole. To help boost credit to the private sector, an IDB line for US\$400 million, through which the central bank purchased high quality loans from commercial banks, was approved in December 2008. ${ }^{15}$ The three percent liquidity requirement that had been instituted for the elections was gradually withdrawn starting in April.

Table 4. El Salvador: Financial System Projections and Outturns

\begin{tabular}{lcr}
\hline & SBA 09 1/ & Actual \\
\hline & (million U.S. dollars) \\
Net international reserves & 2,482 & 2,985 \\
Free NIR 2/ & 129 & 573 \\
Nonfinancial public sector deposits at the central bank & 217 & 614 \\
& (percent change in 2009) \\
Commercial banks: Private sector deposits & 1.5 & 2.3 \\
Financial system: Credit to private sector & 6.4 & -4.6 \\
Broad money & 3.4 & 2.0 \\
\hline Sources: Central Reserve Bank of El Salvador; and Fund staff estimates. & \\
1/IMF Country Report No. 09/71. & \\
2/Free NIR are defined as the difference between the central bank's net international \\
reserves, which include government deposits, and its liquid liabilities with domestic residents.
\end{tabular}

\section{Asset quality and profitability deteriorated, but banks maintained sufficient} liquidity and capital buffers. NPLs rose from 2.8 percent of total loans at end-2008 to 3.7 percent at end-2009, with the associated provisioning cutting profitability (Table 5). Banks increased their liquidity and capital ratios in line with banks in the rest of the region by shifting to low-risk, liquid assets, and held excess reserves at the central bank through most of the year. NIR came in well above target as private sector deposits grew and the government accumulated more deposits than programmed.

Table 5: Financial Soundness Indicators

\begin{tabular}{lcrrrrr}
\hline & \multicolumn{2}{c}{ El Salvador } & & \multicolumn{2}{c}{ Other Central America 1/ } \\
\cline { 2 - 3 } \cline { 5 - 6 } & 2008 & 2009 & & 2008 & 2009 \\
\hline Return on equity (percent) & 8.7 & 2.8 & & 23.1 & 16.3 \\
Nonperforming loans (percent of gross loans) & 15.1 & 16.5 & & 14.0 & 15.1 \\
Capital adequacy ratio & 35.7 & 41.3 & & 37.4 & 40.7 \\
Liquid asset ratio & & & &
\end{tabular}

Sources: National Sources; and Central American Monetary Council.

1/Simple average of Costa Rica, Dominican Republic, Guatemala, Honduras, Nicaragua, and Panama.

\footnotetext{
${ }^{15}$ Usage peaked at US\$180 million in April. The downturn in credit demand, along with the loan's complexity and high cost, dissuaded banks from using more of the funds.
} 


\section{Approval of the Financial Sector Supervision and Regulation bill was delayed,} limiting progress on the key objective of strengthening the financial sector's ability to withstand shocks. The outgoing authorities shared the draft bill with the incoming economic team after the elections. However, the new authorities needed more time to review and modify the draft bill before pushing for its approval. They also faced other policy priorities related to coping with the greater-than-expected impact of the crisis on the real economy and the need to provide social protection. The bill has been revised in the new congress which added provisions facilitating the use of IMF funds for lender-of-last-resort operations. The authorities have also undertaken an FSAP update, in which options to enhance the central bank's capacity to channel liquidity to the financial system were studied in depth. The authorities hope to build upon the recommendations of the FSAP in developing a mediumterm strategy for liquidity provision under the dollarized regime. With hindsight, the timing for the passage of this bill in the original program proved to be ambitious and could have better internalized the political realities that an outgoing congress would be hesitant to precommit its successor and that a new congress would need adequate time to deliberate on the bill.

\section{Request for New SBA}

\section{Given the large fiscal slippage, the incoming authorities preferred to formulate their own long-term fiscal program rather than bringing the SBA back on track.} Importantly, the fact that staff had reached out to the new authorities prior to the elections helped to maintain a framework for policy discussions even though the program had gone off track. The SBA gave the Fund the opportunity to remain engaged during the political transition. This engagement helped avoid a buildup in domestic arrears during the transition which would have been detrimental for the credibility of the macro framework. An outreach seminar was held in May 2009 in conjunction with the World Bank and IDB that was attended by the President and the economic cabinet. In the event, the new authorities were keen to take ownership of a new program that would present to investors their medium-term plans for fiscal consolidation. Staff supported the strategy since ownership is key to program success. Besides, given the magnitude of fiscal slippage, program design would have had to be adjusted substantially and it was appropriate to have a longer lasting arrangement. Such a strategy was also consistent with the Fund's experience as there have been several cases where, after a change in political leadership, the new authorities have canceled an existing arrangement and requested a new arrangement. ${ }^{16}$

\footnotetext{
${ }^{16}$ Approximately 150 arrangements have been cancelled since 1952 , about 10 percent of all arrangements. Of these cancellations, approximately two-thirds were replaced with a successor arrangement within one day of the cancellation. The main factors for such cancellation-and-replacements have included political developments, a major program re-design with additional financing, and changes in maturity.
} 


\section{The September 2009 staff-level agreement on a successor arrangement} demonstrated the new authorities' commitment to fiscal sustainability. Staff and the authorities reached agreement on a three-year SBA that geared fiscal policy toward supporting domestic demand during 2010, while safeguarding debt sustainability through a sound medium-term plan of fiscal consolidation. Board approval was delayed until March 2010 because of the need to incorporate into the macroeconomic and fiscal framework the effects of Hurricane Ida, which occurred in November 2009, and to meet the prior actions. These included a revenue package estimated to yield $1 / 2$ percent of GDP on an annual basis, which demonstrated the authorities' commitment to fiscal and macroeconomic stability, in line with the intent of the 2009 SBA.

35. The new SBA builds on the lessons from the old SBA. E1 Salvador has used up its fiscal buffers and now needs to embark on a medium-term program to improve fiscal sustainability. The new program therefore focuses on fiscal measures. Strengthening the financial system, including through the passage of the financial supervision and regulation bill, remains a key priority and congressional approval of the bill was included in the new SBA as a structural benchmark.

\section{Conclusion}

36. Quick, coordinated action, with large provision of liquidity and effective use of IMF's lending facilities can be effective in preventing a crisis. The IMF's response in El Salvador was the reflection of a broad effort by the institution to provide tailored assistance to its members in a timely fashion. The success of the program shows that crisisprevention instruments can play a useful role.

37. The El Salvador program is a good example of effective Fund support during a political transition. Public endorsement of policy continuity by the two leading presidential candidates was a key aspect of the arrangement's objective to bolster confidence. The SBA contributed to the smooth political transition by helping to generate dialogue between the outgoing and incoming administrations. At the same time, the proposed timing for approval of the financial law could have taken into account the complexities in achieving congressional approval of a major structural reform two weeks before a change in administrations.

38. Large deviations between initial program projections and outturns often require a major re-think of program objectives and design. In El Salvador's case, the much bigger-than-expected impact of the global crisis on the economy meant that public debt has risen much more than expected. The new SBA therefore places greater emphasis on preserving fiscal sustainability. 
Figure 1. Macroeconomic Fundamentals on the Eve of the Crisis
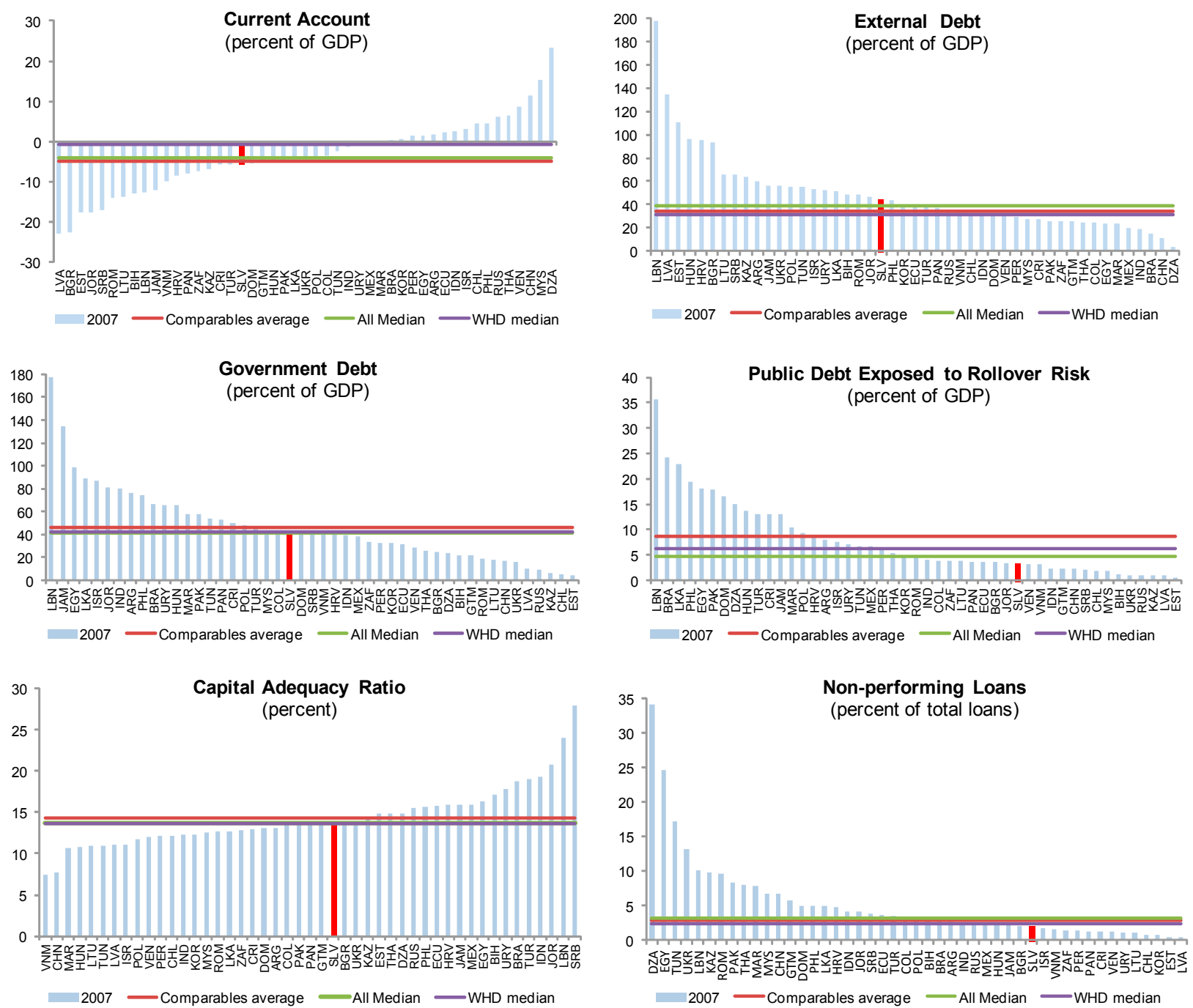

Source: Fall 2008 Vulnerability Exercise for Emerging Markets. "Comparables" consists of Dominican Republic, Costa Rica, Panama, Guatemala, and Uruguay, following the country analytical groups in the Regional Economic Outlook: Western Hemisphere and subject to data availability. 
Figure 2. Relative Macroeconomic Performance ${ }^{1 /}$
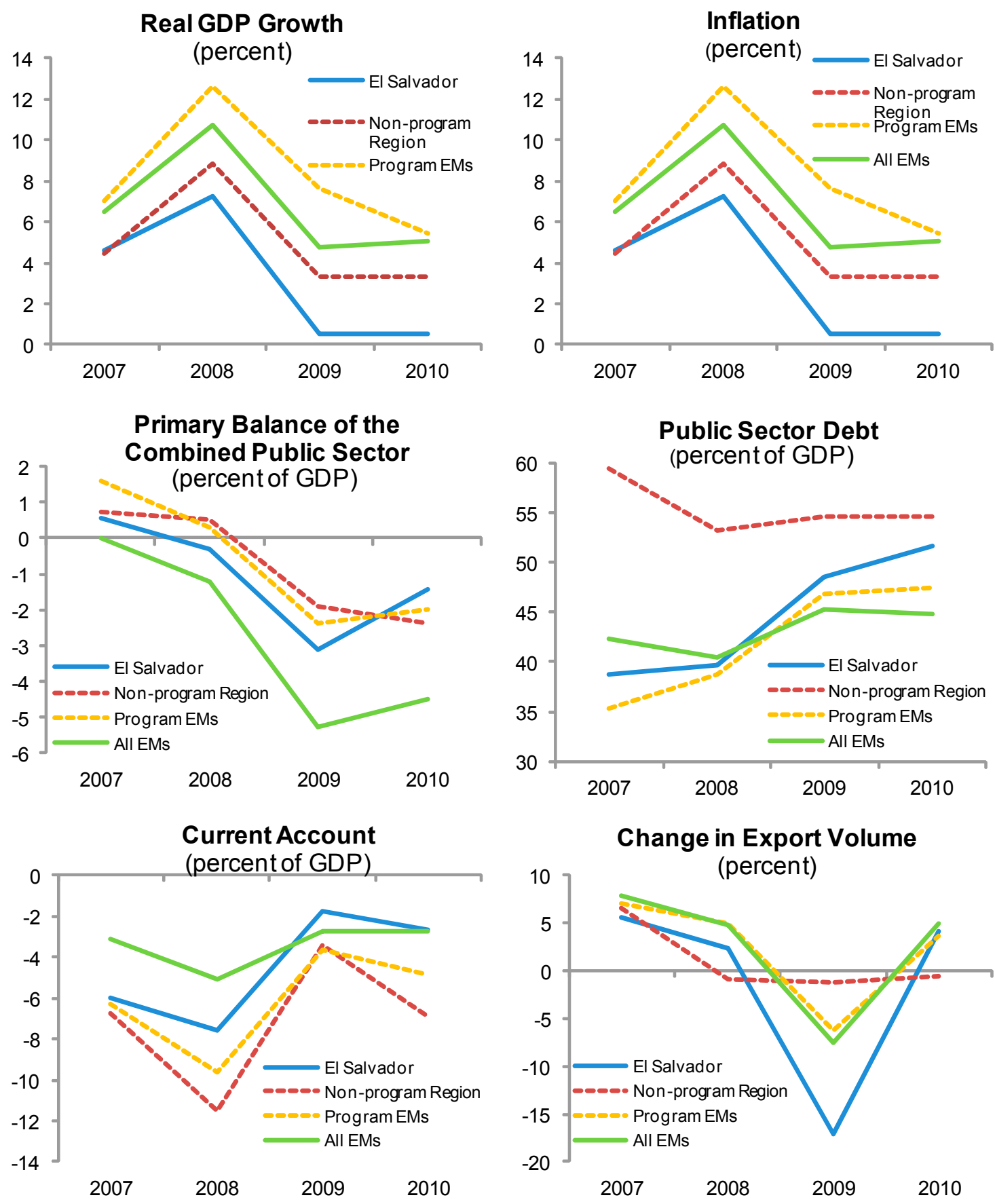

Source: WEO.

1/Non-program region includes Belize, Honduras, Nicaragua, and Panama. All the country-group series are averages within groups. 


\section{Annex I. Authorities' Response}

The authorities agreed the program helped to avoid deposit outflows by bolstering confidence around the time of the elections. They thought the program played a positive role in signaling policy continuity, including through the public endorsement of the program's main goals by both presidential candidates, and contributed to the policy dialogue during the transition to the new administration. While uncertainty about the macroeconomic environment was high at the time of program approval, they noted that the initial macroeconomic framework could have been more conservative. In lieu of working to complete the review, the authorities were keen to work towards a new SBA that could be considered their own program and allowed them to demonstrate their commitment to fiscal sustainability over a longer period of time. They also noted that the time that elapsed since the original date for passage of the financial supervision and regulation law allowed them to improve upon the originally drafted law, including by incorporating some of the findings of the recent FSAP update. 


\section{Annex II. Public Statements by Presidential Candidates}

Both leading presidential candidates endorsed publicly the main elements of the SBA, including maintaining macroeconomic stability, fiscal sustainability, and dollarization. Below are their respective statements translated in English based on the text on the campaign web sites. These were shared with the Board at the time of the Request for SBA (IMF Country Report No. 09/71, 01/09/2009). 


\section{Rodrigo Ávila Seeks IMF’s Final Approval for \$800 Million Loan}

"As president of COENA [Consejo Ejecutivo Nacional, National Executive Council] and candidate for president, I believe that this loan and all its associated economic elements will help preserve the macroeconomic stability of our country."

Rodrigo Ávila, President of ARENA [Alianza Republicana Nacionalista, Nationalist Republican Alliance]

Rodrigo Ávila, president of the ARENA party and candidate for president nominated by this political institution, today requested IMF authorities to approve the final allocation for a loan of $\$ 800$ million that will provide "economic security" to the country in the face of the global financial crisis that has shaken the world's major economies and is threatening the emerging economies.

Although a preliminary agreement was reached between the government and the IMF on December 22, disbursement of the funds depends on the approval of the IMF's Executive Board. A decision is to be taken tomorrow, and that is why the president of the foremost national political institution considers it prudent to call for a definitive commitment.

"As president of COENA [Consejo Ejecutivo Nacional, National Executive Council] and candidate for president, I believe that this loan and all its associated economic elements will help preserve the macroeconomic stability of our country, which is crucial for supporting a favorable investment climate, protecting jobs, and preventing the crisis from hitting us with full force and affecting the financial circumstances of Salvadoran families," the candidate for president explained.

Ávila said that obtaining this loan is crucial for preserving the liquidity of the national financial sector and maintaining a sound economy. "The purpose of this loan is to enhance confidence in the economy and provide a liquidity cushion for the financial sector that will allow it to shield itself from the global financial crisis and protect the country from its effects. That is why we once again stress the importance of obtaining this loan," he added.

\section{Ávila committed to respecting agreements with the IMF}

Ávila also made a commitment that, once the agreement comes into effect, he will respect the terms agreed on with the financial institution and the spirit of the loan agreement.

The funds, which would be available within one month and remain so for a period of 15 months, would improve the country's economic security. On various occasions, Rodrigo Ávila has stated that one of his main goals is to maintain the economic stability of the country. 
In this context, the candidate for president has stated that the economic policies of his government program, called "A More Just Country," will focus on firmly establishing the official dollarization policy, establishing strict preventive regulations for the financial sector and a prudent fiscal policy in line with the budget approved by the Legislative Assembly, which provides for expanded social spending to mitigate the impact of the global economic crisis on the poorest sectors of the population.

Rodrigo Ávila finished by expressing his confidence that the decision of the IMF Executive Board would be favorable for his country, and he affirmed that the measures he has taken to support this agreement will soon bear fruit. "When I met with the IMF authorities for the first time last June 17th to discuss this subject, we were certain that these measures would bring great benefits to the Salvadoran people," he said.

\section{Peace, Progress, and Development}

San, Salvador, January 15, 2009 


\section{Statement by F.M.L.N. Presidential Candidate Mauricio Funes on the Agreement between the International Monetary Fund and the Government of El Salvador}

Since the financial crisis began in the USA, I have been concerned about the potential fallout on El Salvador. For this reason, in recent weeks, I have been working hard to study the crisis, to propose specific measures to counteract its repercussions and prevent more serious problems in future, and to identify external political, technical, and financial assistance. Furthermore, and in light of the seriousness and complexity of the international economic and financial situation, I have emphasized that the only way to address the crisis successfully is through national unity, as I believe that El Salvador's destiny is our shared responsibility.

In November I traveled to Washington, where I met with staff of the Inter-American Development Bank (IDB), the World Bank (IBRD), and the International Monetary Fund (IMF). At these meetings I reaffirmed my commitment to maintaining and consolidating macroeconomic stability, preserving dollarization, and implementing a sound fiscal policy geared toward increasing social spending and investment in infrastructure. In addition, I presented my proposals for addressing the crisis, including the establishment of the special strategic reserve fund. In addition, my proposals include other measures designed to strengthen the domestic financial system and to make timely loans to support productive sectors - in particular, the agriculture sector and micro-enterprises and SMEs.

As a candidate for the presidency of the Republic of El Salvador, I repeat my willingness to maintain good relations with international financial institutions and with multilateral banks. Moreover, I am committed to supporting all programs aimed at ensuring macroeconomic stability, increasing social and infrastructure investment, safeguarding the stability of the financial system and curbing the fiscal deficit.

On December 22, the IMF issued a press release announcing that agreement had been reached, in principle, on a program that could be supported by an amount in the equivalent of SDR 513.9 million (about US\$800 million), under a 15-month Stand-By Arrangement (SBA). This press release goes on to say that the Salvadorian authorities intend to treat the arrangement as precautionary and do not intend to draw on it.

I share the general principles underpinning this agreement, especially those having to do with preserving macroeconomic stability, maintaining dollarization, and ensuring prudent fiscal management. Moreover, I wish to express my satisfaction at the inclusion of measures to increase social spending and investment in infrastructure as well as efforts to strengthen the domestic financial system. These are essential elements for generating a climate conducive to domestic and foreign private investment and for achieving greater economic growth for the benefit of the Salvadoran people.

San Salvador, January 15, 2009 